\title{
GLOBAL GOVERNANCE AND DEMOCRACY UNDER THE SHADOW OF THE PANDEMIC
}

\author{
Kivanc Ulusoy ${ }^{15}$, \\ University of Istanbul \\ Andreas Stergı ${ }^{16}{ }^{16}$ \\ University of Thessaly
}

\begin{abstract}
Clobalization and democratization have long been questioned by powerful Western European countries such as the United States of America (USA), France and Britain, who regard these two movements as almost organic elements of their foreign policy. This questioning, which intensifies with the sharpening of global economic conditions, seems to have serious consequences for the future of the Western Alliance. This period comes with ethical and political dilemmas that will profoundly affect the modern individual's view of world politics. In a system where there are no mechanisms to allow non-state actors to participate in government on a global scale, mass protest and destructive moral questioning are inevitable. This situation has become evident with the new type of corona virus epidemic (Covid 19) that has shaken the world since the beginning of 2020. The Covid crisis has demonstrated that human rights and freedoms enshrined in universal human rights conventions have not been adequately respected. Though beyond the focus of this paper, the migration crisis created by the civil war in Syria and the current state of affairs after the withdrawal of the US from Afghanistan are clear cases in this respect. This paper focuses on the dilemmas that politics and ethics in the face of radical, global changes.
\end{abstract}

Keywords: Pandemic, globalization, morality, ethics, power, governance.

Economists ask 'How does this policy affect the welfare of society or a part of it?' Lawyers ask 'Does this policy comply with the rule of law?' Moralists ask, 'Is this policy in line with moral principles?' And political realists ask, 'How will this policy affect the power of the nation.' (Morgenthau, 1967: 11)

\section{Introduction}

Globalization and democratization gained a worldwide strength in the aftermath of the WWII. Never again in world history has an economic and social interaction appeared on this scale. A political system and ideology has not been active at the global level in a hegemonic manner. This situation, considered as a systemic domination created by capitalism and liberal democracy at the global level, cannot be explained independently from the international political structure and power relations of the post-war period (Skidmore, 1997).Recently, the post-WWII globalization and democratization have been questioned by powerful Western

\footnotetext{
${ }^{15}$ Contact address: kivancu@istanbul.edu.tr.

${ }^{16}$ Contact address: snandreas@hotmail.com.
} 
European countries such as the US, France and Britain, seeing it like almost an organic element of their foreign policy. They have endorsed the international political and economic relations built around the global institutional structure mainly centered in the Western capitals but also in the World Bank, IMF, World Trade Organization and the European Union (EU). This questioning, intensified with the sharpening of international economic conditions especially after the 2008 financial crisis, would have consequences regarding the future of the Western Alliance that took ground during the Cold War era.

In the last seventy years, the traditional structure of international politics since the nineteenth century based on based on balance of power and temporaryalliances has undergone significant changes. After the two world wars, the international system was knitted with institutional structures that spread to almost all public issues with its expanding scope. After more than forty years, the bipolar structure shaped by the ideological competition between the Eastern Block led by the Soviet Union (SU) and the Western Alliance under the leadership of the US since the end of the Second World War unexpectedly collapsed. After the World War II, liberal democratic regimes established in Western Europe and the multilateral international economic and political structure supporting them emerged as the basic building block of the international system.Now, almost thirty years after the end of the Cold War, the fundaments of this system are put in question.Alternative power centers, non-state actors not limited to institutions but including individuals, and different issue areas and values has come to the fore.

This newly emerging system is not independent of power relations (Waltz, 1993). After the end of the Cold War, liberal democracy, expected to have a global validity, has entered a period in which it has been perceived as a 'great power ideology', and lost its previous value. On the other hand, free trade has become utopia due to the increasing protectionism by the USA, China and the EU, hitherto carrying this as a flagship (Ruggie, 1982; Ish-Shalom, 2006). We gradually come across an order where 'development' is again measured on a national scale. The US role as the guarantor of the post-war order has been challenged by Russia, China and the EU. The global liberal order now is dramatically weakened by the emergence of a China almost equal in power with the US but with profoundly different values. The confrontation stemming from this difference looks inevitable. But, the US is not very keen to carry this multilateral institutional structures and diplomacy-based order that has long worked in its own interest (Mayo and Peros, 2011).On the other hand, this new era comes with ethical and political dilemmas that will deeply affect the modern individual's view of world politics. Despite all the international institutionalization efforts of the post-World War II era, mass protest and a destructive moral questioning are inevitable in an international system where the mechanisms that allow non-state actors - individuals, classes, ethnic and religious groups - to participate effectively in government on a global scale are not formed (Yesilada, 2006; Marchetti, 2009; Kim and Urpelainen, 2015).

This situation has become evident with the new pandemic that has shaken the world since the beginning of 2020. In this period when Covid 19 brought the global economy to a halt, the leaders of important Western countries seriously argued that some should die for the majority to survive and benefit. This proposal, which is nothing more than a moral bankruptcy, showed how tragic the situation as health workers at the forefront of the epidemic 
overwhelmed by cases had to make difficult choices to ensure the survival of patients. On the one hand, where there are few medical devices, such as ventilators, it has emerged as a painful dilemma which of the two critically ill patients is worth saving. On the other hand, the leaders of these important Western countries could easily say that they should sacrifice lives to save the economy, causing indignation in their own societies. The moral burden for a conscientious person of such a choice, which would result in the death of both patients, is not an easily borne one. The situation faced was a test of religious belief for believers and a test of tolerance for secular individuals. The pandemic has forced everyone to ask the profound questions of human existence that philosophers have been asking for centuries, and to face basic moral dilemmas.

The global epidemic, literally a test, has pushed individuals around the world to take a position on fundamental moral issues. What is the right and wrong choice? What can the individual expect from society? What can society expect from the individual? Should others sacrifice for me? What can I do for them? Should we limit economic life to fight a deadly disease? Should we risk prolonged uncertainty and misery to save someone's life? Politicians (supposed to be responsible for the benefit of all) answer these questions from one window, and individuals (supposedly responsible to society) from another by isolating themselves (or not) for the sake of others' health. As the pandemic worsens and the disease equates everyone, the idea of loving our neighbor as ourselves becomes stronger. But time could easily reverse feelings in such situations. The prolongation of the pandemic process, the delay in the availability of the vaccine will make individuals opposed to each other, as well as the economic shutdown process and growing social problems may make it inevitable to pay a humanitarian diet to maintain well-being.

In this context, the pandemic soon raised a series of ethical dilemmas and emerged as an acute crisis of global governance. First of all, both the political choices of governments and the personal choices of individuals brought a deep ethical questioning with them. China, where virus cases were first seen, had the responsibility to report these cases to the rest of the world, and thus had the chance to ensure that other countries took the necessary precautions on time. Although the World Health Organization (WHO) has been informing developed countries about a possible pandemic for some time, it turns out that this organization, like many other international organizations, has lost its function and is not taken seriously. In such a critical public policy area, we see that the WHO has no power to direct countries, let alone governing the global struggle against virus. The process of international institutionalization in the post-World War II era brought forward marginalized institutions without sanctioning power. We have seen that the health, public health and social security systems essential for the legitimacy of states come to the brink of collapse. It turned out that the reason for this was the neo-liberal economic policies followed for a long time. The financial crisis of 2008 brought a world-wide recession that has not been seen since the Depression of 1929. However, the exit from the crisis did not go beyond injecting money into the markets and the ultimate aim was to save the economyin a short time with the least damage, preventing social unrest and possible chaos. Beyond that, proposals for a serious restructuring in global production and commercial schemes have still not come neither from intellectuals nor from active policy makers. 
This article focuses on political and ethical dilemmas in the face of radical changes that come to the fore in the global context. The first section summarizes critical developments experienced worldwide in the effect of the new type of corona virus pandemic. It focuses on the policies followed by governments in developed Western countries and their possible moral, political and economic effects. We try to situate this in the perspective of international politics within the context of ethical inquiries and theoretical debates. Our assessment closely relates to dynamics of change inthe post-war international system and the possibility of the establishing a new structure. The concluding remarks return to the discussion about Covid-19 and put forward the albeit weak alternative political and economic approaches created by the global epidemic in the West.

\section{Epidemic, Democracy and Governance}

Europe became the epicenter of the epidemic in early March 2020. In a short time, Italy became the country where Covid-19 hit the hardest after China. After weeks of strict 'stay at home' policy, death rates in Italy decreased, but the situation in the US did not change for a long time. Daily death statistics quickly surpassed hundreds or even thousands. Cases have not spread evenly around the world. Lombardy in Italy, Madrid in Spain, Wuhan in China and New York in the US were the worst affected places from Covid-19. Turkey had the highest number of cases outside Europe and the US. Over time, the daily death rate in the afore-mentioned two regions in Europe, where the epidemic increased rapidly, started to trend horizontally. The city in the most difficult situation in terms of combating Covid-19 in the world remained New York for a long time. Despite the red alert in the period when the new type of corona virus was spreading rapidly in the developed West, the international response remained late, ineffective and incomplete. It was not possible to give a global response to the epidemic, which manifested itself as a worldwide governance and leadership problem (Tisdall 2020). Especially food companies, farmers and non-governmental organizations started to point to a wave of hunger due to the possible collapse of food supply chains and closing borders. Although the need to prevent the pandemic from turning into a global humanitarian crisis forced inter-state coordination, WHO, which was expected to be the leading actor for a coordinated response to this epidemic was inefficient from the beginning. The pandemic, considered as the biggest global science policy failure, was a test of medical capacity and political will on the one hand, and revealed the bankruptcy of politics of science, on the other (Horton 2020).

While most European countries were implementing a 'shutdown policy' to stop the spread of the pandemic, several countries preferred a different strategy. This strategy was called 'herd immunity' first proposed by the British Prime Minister Boris Johnson, who refused to implement 'social distance' measures. Johnson, after he was tested positive for the coronavirus in early March, asked the British people to 'be ready to lose their loved ones'. The British government allowed the virus to spread uncontrolled in the hope of gaining 'herd immunity'. Johnson's adviser Cummings argued at a private meeting that if nationwide 'herd immunity' meant the death of some retirees to save the economy, enough people should be allowed to get sick. In this equation, the British government argued that for someone to live, you had to let someone die. Following these rhetorical statements, Downing Street immediately followed a policy of denial. Johnson and Cummings had to reject this 'utilitarian' 
politics in the face of social indignation against the statements. It is a characteristic of British conservative politics to see moral problems through a 'utilitarian' lens and to see that they conflict with basic moral principles in the face of their unpleasant consequences. However, provided that the current situation - 'lockdown' and 'social distancing' - lasts for months, these ideas could be faced again. The pandemic tragically showed that the British 'utilitarian' thought and politics are still standing. However, this argument cannot be said to be a coincidence. On the contrary, it was found to be part of a comprehensive political strategy. While 'herd immunity', the politics of watching the deaths of some people to save the economy, horrified the British people, many quietly agreed that this was a diet to save capitalism. Similar phenomena have been registered in India, Cuba, and South Africa and in Balkans. In all these countries, repeated public demonstrations reflect legitimate grievances in the population about the lack of proper health care as well as freedom of expression and freedom of the press. In parallel with the Covid-19 situation, these grievances have created an increase in the demand for civil and political rights, and for democracy.

The choice of who lives in the country and who is allowed to die may seem like an inevitable choice. In fact, if even one person does not want to be abandoned, governments do not have the right to give up on him. Politicians must do their best to protect everyone, especially the weakest, as per the basic ethical rules on which politics is based. Implementation of strict 'lockdown' measures has shown that health systems are on the verge of collapse since in many cases neoliberal economic policies have been followed for years. The "herd immunity' approach that the British government initially tried actually seems to be part of the stripping strategies by blaming the failure of the health system on the virus rather than admitting a policy failure and bad management. The next step is to blame poor and sick people who have to leave their homes and work for not following quarantine measures. For politicians, it is acceptable to be individuals responsible for nature, fate or their own fault and facing the consequences of their own choices, as long as the responsibility for their deaths does not rest with the government (Frey 2020).

The than US President Donald Trump also advocated a much darker version of the same equation (Falk 2020). Trump and like-minded US officials said the economy cannot be allowed to collapse, even if it means sacrificing some lives. Three days before the US took the lead in becoming the country with the highest number of confirmed Covid-19 cases, Trump said he would soon return to normal working life, despite warning by healthcare professionals. It is hard to believe, but the return to the age of human sacrifice in the West in the 21st century was almost real. Texas Deputy Governor Dan Patrick said on Fox News that the elderly could be sacrificed for the economic interests of young people, and that he would accept this as an elderly citizen over 70 years old who is likely to be affected by the virus. This view has been defended by many commentators in the conservative American media. This showed that political brutality was more than a marginal voice, but the epitome of the Republican outlook. Again, Trump said in a Tweet, 'We can't let the cure get worse than the problem'. But, he was shocked when New York had an estimated 5 percent of the cases in the world due to inconsistent policies followed since the start of the pandemic (LeBlanc 2020, 2020a).

However, the idea that 'social distancing' measures that shut down the economy would bring about a devastation ( $20 \%$ or $30 \%$ unemployment estimates in the second quarter 
of 2020) pushed Trump (and his conservative supporters) to insist on this rhetoric. After all, the thought of not sacrificing the economy at the expense of the lives of the elderly was seen as an appropriate exit. Someone could maybe argue that this view includes the following expectation: the old, disabled, inefficient, socially and economically unfit will disappear with the pandemic. The debate that came to the fore in the US in terms of choosing to save lifes or to save economy posed a moral dilemma misleading the public. Equating human lives with money is an unacceptable moral point of view for some prudent sectors of the American society. But, the pandemic showed that, like the previous ones, such a 'zero-sum' way of thinking is possible for those seeking political or financial interests, regardless of the cost (Gak 2020). The choices we make as a society during this crisis will largely determine who we are after the pandemic. But the choices made by politicians and individuals, consciously or not, find themselves in different moral traditions. The pandemic has arisen deep philosophical questions and continues to shake deeply the moral universe of a modern man (Authers 2020).

When the pandemic started, leaders and mainstream media chose to define it as a 'war'. However, claiming this to be an extraordinary situation and attributing to the current crisis a state of total 'war' that requires a complete 'mobilization' only served to dispel a healthy political debate. After the pandemic, as most journalists, academics and intellectuals from the mainstream Western media stated, this crisis showed that nation-states were important, despite the widely accepted statement of globalization and the dissolution of states' sovereignty. However, this new process opened by Covid-19 shows that which of the states we are citizens of is equally important. Although the pandemic is a global phenomenon, as we have tried to demonstrate in the UK and USA examples above, the impact of the disease is largely shaped by the decisions of governments. Differences in when to act and how far to go separate countries from one another. Over time, it will be seen more clearly which country did what is right and what is wrong. For now, countries are at the mercy of their own leaders and political elites. Nowadays, when the article was written about the second wave of the epidemic, scientists insist that governments should listen to warnings now. The leaders, on the other hand, try to persuade the peoples to more delightfully self-sacrifice by declaring a mass mobilization with the discourse of an emergency, 'a state of war' against an invisible enemy.

The English philosopher Thomas Hobbes was talking about exactly this about 400 years ago. Hobbes underlines that in essence the individual political judgments of countries and leaders are entirely arbitrary. According to him, it is impossible to avoid the 'arbitrariness' element at the center of politics. The common aspects of democracies with other political regimes are evident under the kinds of political crises caused by the policies of emergency such as 'closure' and 'social distance' that emerged with the pandemic. From this point of view, it seems that politics is basically about 'power' and 'order' and, by its very nature, final decisions are deeply related to how power will be used. Beyond being a technical problem, this is a situation that makes arbitrariness inevitable. Democratic or autocratic, the way power is used with these decisions shapes our lives. We are far from the violent world that Hobbes tried to escape from, but our political world is still a world that Hobbes would recognize (Runciman 2020). 
In this context, perhaps the most serious conceptual tools that will help us to decipher the social, political and economic crisis caused by the pandemic offer the ideas of the French philosopher Foucault on 'sovereignty' and 'regimes of power'. Foucault's views on 'biopolitical', 'governmentality' pointed to a new mode of 'power' that came to the fore in the West quite early. From Foucault's point of view, the pandemic has made it clear that the 'sovereign' is no longer hegemonic (Foucault, 1991: Gordon, 1991; Tribe, 2009; Dillon, 2007). On the contrary, the sovereign is entirely subordinate to the command of political economy, to the sociological and economic conditions created by capital and by force. For Foucault, who deciphered the rationality of the 'neoliberal' era that has marked our lives in almost the last forty years, the state is not even a 'night watchman' state as in the classical liberal period. It is nothing more than a tool governed by economic logic and capital. In this context, the idea of 'letting deaths to save lives' reveals the real logic of the discourses of politicians such as Johnson and Trumpthat the idea of creating jobs and consumption under the rule of the market is the real momentum behind the social order (Clover 2020).

Pharmaceutical companies often abuse patent laws. What will happen when this pandemic threatens to collapse the social and economic fabric of countries, as we have seen in the last year, and the world desperately awaits a vaccine? Beyond the realities of the free market, from a purely moral point of view, we can say that the treatment should be developed rapidly and easily accessible to all to alleviate the fear and pain of the masses all over the world. This cannot be achieved by granting a special patent to a notorious pharmaceutical giant who chases profits, sets prices, and thwarts competitors. The main lesson that emerges here is that in an industry dealing with the invention and production of life-saving drugs, an absolute market and profit concern is clearly contrary to the well-being of the people (Rahnema, 1997; Fine, 2011; Johnston, 2011). The main reason for this worldwide vulnerability to the virus is the insufficient financial incentive of the public pharmaceutical industry to develop new antivirals and antibiotics. This is exploited by companies whose mission is profit, not public health. In this new process caused by the global epidemic, it seems inevitable that the pharmaceutical industry will be under public control on behalf of humanity (Day 2020).

Since the 1930s, there has been no apparent collapse in global trade with a drop in prices and a simultaneous economic decline until the Covid-19 outbreak. Although the origins of the current shock and the policies applied against it are different, 'lockdown' and 'social distancing' measures brought great costs. This health emergency, which now comes with a global epidemic, is on the verge of turning into a deep financial crisis. Although countries are affected differently from this crisis and we still do not know how long this situation will continue, given the scale of this shock that shrinks demand and disrupts supply, its effects on the economy are likely to exceed the 2008 financial crisis. History has shown that pandemics rarely create economic crises. There are not many comparable examples available, except for the 'Spanish flu' that broke out during the World War I. However, this time the situation looks different due to the policies followed (Reinhart 2020). Governments around the world have tried to limit the spread of the disease through 'lockdown' of a region such as China or the entire country as in Italy and Spain. Many countries, including the US, imposed strict international travel bans and chose to ban public events. This does not require ignoring the large number of invisible workers who are still forced to work. On the one hand, employees of catering companies serve homes and cargo companies transport books, medicines and 
furniture. On the other hand, people give up quarantine after a week or two for economic reasons and return to work. All these show that the economy is the core criteria in assessing our recent experience (Clover 2020).

Immediately after the Covid 19 outbreak started, central banks all over the world reduced interest rates to zero or below, and money was injected into economies. Initially, the US central bank FEDand other central banks expanded the scope of purchases from treasuries and securities to corporate bonds and mutual funds. Central banks from the USA, stuck in Europe, announce extraordinary fiscal stimulus packages to control the situation under the panic of collapsing stock markets. In 35 OECD countries where about 10 billion people live, the gross national product fell more than 1.3 percent in the second quarter of 2020. This decline is sharp in countries that have been most severely affected by the virus to date and have responded with the harshest measures, such as Italy, France, Spain, the UK and the USA. It was easy to see that the rest of 2020 would also be economically bad (Blunchflower 2020). Goldman-Sachs estimated that in the very beginning of the crisis, unemployment figures could easily hit 2.5 million. This frightening prediction soon turned out to be an optimistic one. The American Congress announced a $\$ 2$ trillion war-like rescue plan with a $\$$ 367 billion loan program for small businesses, $\$ 130$ billion for hospitals, and a $\$ 1,200$ check for Americans, earning up to $\$ 75,000$ a year. This package has been extended to include other industries including uber drivers and concert workers. But, the rising prices presented a serious crisis for Americans who no longer had income to pay mortgages and rents. During the writing of this article, Joe Biden, then the Democrat presidential candidate, speaking on the economic effects of the pandemic in Wilmington, said that since the beginning of the pandemic the number of unemployed increased to 11.5 million. The situation was urgent. President Trump was unaware of the seriousness of the deepening economic recession.

\section{The Epidemic and the Hegelian State}

Perhaps one of the most important pillars of realism, which can be considered as the founding approach of the International Relations discipline, is the definition of the political field as an autonomous area from other fields and its strict attitude that political practices should be evaluated according to political criteria (Morgenthau, 1946). On this occasion, realists both attribute an autonomous level to the political field and emphasize that it has its own set of moral rules. The moral values of this field, that is, the values that can be evaluated as 'good' and 'bad' can be directly understood with political reality. In this context, a statesman can be evaluated only on the basis of political results, as well as morally, only with reference to real conditions. Even though this was emphasized by Max Weber (2004) as a requirement of the profession long ago, this is the case even more clearly for international relations.

On the one hand, the statesman, who evaluates himself in terms of power and survival in domestic politics, has the shield of national interest, which is considered the highest value, on the other hand, his only compass in an anarchic environment where moral and legal values are relatively determined is how these interests are maximized (Nardin, 2011).This state, determined by the German philosopher Hegel in the most ideal way, is at the moral peak of the society where it reflects not only the transfer of authority and capacity through a contract, but also the cultural, ethnic, traditional and moral accumulation of the society in 
question. As political theorist Andrew Vincent rightly stated, it is possible for this state to coexist with other states and the rules, values and practices that will develop between states over time will create a modus vivendi (Vincent, 1983; Smith, 1983; Vincent, 1988). It is also possible to live together in peace, not in a state of absolute war. But, a world government or a legal unity, a 'sovereign' state that dominates the states is not possible because each state is the ultimate representative of these moral values, good and right.

In this case, not only because of irreconcilable interests or anarchic structure, as many realist thinkers do, but being a state itself presupposes an understanding that literally imprisons ethical discussions within the borders of states. In such a relative structure, it is not possible to prolong the ethical and moral debate (Cohen, 1984; Rengger, 1997). Moreover, it is not possible to put supranational normative and moral values, which accept the rationality of a German philosopher Immanuel Kant as the main one. It is not possible either to think that these will affect the behavior of states as the scholars of 'democratic peace', seeing them as followers of Kant in the twentieth century (Doyle, 1983; Dryzek, 2010; Lijphardt, 2008). In short, in international relations dominated by the idea of the Hegelian state 'ethics' corresponds with the ethics of 'sovereignty'. A moral political structure that will rise above the structure of sovereign states will not be possible at least in the near future predicted by Hegel (Boucher, 1994).

However, the global political and economic crisis that emerged with the Covid-19 pandemic hasdragged into 'turbulence' boththe'order' in the international system - defined as a long-term 'lack of war' and 'stability' - and the Hegelian state, in the words of James Rosenau (1992). As highlighted above, the pandemic has left governments around the world faced with a critical choice of 'whether to save the economy or human life'. It has literally pushed individuals into a moral crisis and impasse by making them camp on this issue. The pandemic that emerged as a result of the new type of coronavirus pushed the lonely individual of modern life into a dramatic isolation, as in the figures portrayed in an absolute alienation and isolation in Edward Hopper's paintings (Jones 2020). For a long time, especially with the effect of economic globalization and technological developments, change in international politics requireda transition from a 'state-centered' approach to a 'society-centered'one. The pandemic tragically shows us that this ideological perspective shift will not be enough without moral questioning. In this context, the question is not only the widespread understanding that states are the sole and most determining actors of the international system, but also that economic inequalities, which have long been seen as a problem of development, cannot be eliminated without transparency and solidarity at a global level (Ellis, 2009).

A state of 'turbulence' caused by the pandemic can act as a catalyst for the transition from 'government' to 'governance', which has been discussed for a long time in academic circles. Time will show that. The political system arising from the anarchic nature of international relations actually predicts not a government from above, a world state, but on the contrary a horizontal administrative relationship. However, the main problem here is that the discipline sees states as primary elements of the international structure (Wendt, 1992). Ensuring national interest and sovereignty should be possible within a system of common values freedom, justice, and environment - that can be achieved without a world state. However, this situation necessitates an ethical approach beyond the ethics of 'sovereignty', the only 
ethics that the international relations are based. The traditional approach of international relations regards statesmen as transformative elements of the international system as the primary actors who make moral choices - real choices about good and bad, war and peace (Biersteker, 1992; Zurn, 2000).

This traditional international political perspective, while neglecting the growing pluralism in international relations, fails to respond to the radically transformative effect of technology on these relations. The pandemic has clearly revealed an issue that has been on the agenda for a long time, that technology has ceased to be a function of state interest and power, but, now determines its decisions. The first discussions about technology being so determinant came to the fore with the developments in atomic technology and the discovery of the atomic weapon after the Second World War. The pandemic has put this issue back on the agenda. With the Covid-19, a heated ethical debate began with the realization that technology is a phenomenon that shapes the conditions for critical public decisions. Thisrelates to the debate about the ultimate goal of technology and science, disproportionating the power relations between states. In this context, a vitally important moral responsibility falls on scientists. Especially in the case of developing a vaccine against Covid-19as critical as the defeat of the epidemic, the scientists who tells the truth, defends the society and makes sacrifices, becomes a respected actor in the new global social, political and economic structure after the pandemic.

\section{The pandemic as a crisis of government}

As a result of a period of rapid globalization, in which production has shifted to East Asia due to cheap labor, developed countries are left with an aging population, immigration and refugee problems that have reached incredible levels. Environmental problems than have made parts of the world uninhabitable (Waltz, 1991). Even the EU, one of the international institutions developed with great hopes after the World War II is in an acid state, exhibiting both a crisis of governance and solidarity in the face of the Covid-19 pandemic. The pandemic made apparent the weakening of solidarityin joint response to the common problems. With the Covid 19, the weakening in these founding elements of the EU, already shaken in the 2008 economic crisis, has deepened rather than recovered. A deep crisis of trust seems to have settled in this 28-member union (Varoufakis 2020). On the other hand, what has long been called the 'Clobal South'- a large part of the underdeveloped and developing countriesis completely abandoned to its own fate. The expanding pandemicin these countries shows that theirlack of 'state capacity' to persuade people to stay at home to prevent the health system from collapsing. Some of them don't have the basic health care system and enough financial power required to combat a mass epidemic.

As these 'social isolation' measures are enforced in some countries, they have revealed that a small number of the educated middle class and a small institutional power operating with brute force constitute the basic political structures seriously suffering from legitimacy problems. The dying of the masses seems inevitable in these countries. Probably they have not been correctly reported, just like in China or Iran. These structures, which avoid transparency even in simple financial matters or human rights violations, are not expected to report such a situation transparently.Another important issue is the acute immigration and refugee problems that manifest themselves after military interventions and civil wars 
in Afghanistan, Iraq, Libya and Syria. The refugee camps all around the world have been the centres or the most obvious targets of the Covid 19 virus. In combating the pandemic, 'social isolation' and 'hygiene', emerged as the most and only effective method for now, seems impossible to apply in these camps. The lack of sufficient medical personnel and equipment is another matter. Health workers reporting from these countries state that the situation reached an extremely bad levels, making their work almost impossible. Emphasizing that even their own lives are in danger, healthcare professionals say that it will soon be impossible to find even health personnel to serve here.

In this case, it is even difficult to argue that the world is governed, let alone the creation of a more just and fair system of governance around the world. The pandemic revealed a global crisis of 'governance'. A transition from 'government' to 'governance' envisions a gradual emergence of a problem-solving mechanism from a state-centered one to a horizontal one taking into account as many actors as possible and allow their participation. The expanding use of 'governace' envisaged a more participatory structure including non-state actors on their agenda. But, as the Covid 19 shows the present situation is completely ungovernable one.The 2008 finacial crisis provided some clues about the present state of ungovernability. It revealed a series of structural problems in global politics and economy: deepening differences in levels of development and rising inequality; lack of financial transparency; easy resort to protectionism in national economies; and international institutions failing to formulate a common response.

The issue of global interdependence in politics and economics is another case that has to be reconsidered in the present context of pandemic. It has been known for a long time in the academic circles of both developed and developing countries that there is no real interdependence and that the trade and capital relations that are in question are mostly concentrated among developed countries. Beyond these geographies, which are the source and focal points of technology and scientific developments, it turned out that there is a dependence on these regions by the rest of the world, sometimes indirectly and sometimes directly at the colonial level, in terms of technology and capital. This situation emerged dramatically, especially in the post-Cold War period, due to the increasing political instability, collapsed states and economic structures in the so-called 'global south'. It is known that these countries of the 'global south', which no longer have anything to sell to buy technology and industrialize, are mostly carried out by international companies to process their natural resources and to move and use them to central countries. Political powers in these countries have become hostages of political, economic and mafia actors in developed countries due to the corruption they have sunk to their throats. These corrupt governments, which are mostly pursued by international criminal courts and judges, are incapable of developing mass mobilization or even a common policy at the UN level that will support the formation of a fairer world, not to rule their own countries. In this sense, it is not easy to sustain the realist view that the state is standing firmly and well.

\section{The epidemic as a crisis of democracy}

The Covid-19 outbreak was also a test for American global leadership. The postWorld War II liberal democratic political system and the globalized liberal economic structure survived, largely thanks to the global American leadership. They survived to the extent that 
American political and economic power supported it. This issue is an indisputable reality in many ways. Two questions need to be answered here. The first question is why the American leadership shows this political and economic support. To this question, some argue that the US has already attributed such a moral mission to itself. The US has already seen the order it idealized as the best for the world. In this context, the struggle against communism was already gaining moral significance and ideological legitimacy. American idealists and some realists vigorously defended and idealized this foreign policy. A multilateral approach, attaching special importance to the US acting with allies, coordinating and leading them, has been advocated largely through elite cadres not only in the US but also in the allied states mainly in Europe.

However, according to some vigilant and realistic approaches, neither the US nor any other state would have much of an opportunity in the existing (anarchic) international political structure. Some classical realists, such as Carr (1945), objected from the outset. In later periods, the structuralists, such as Waltz, argued that the international system would not allow this. Two things can be said in this context. The American multilateral approach can only be defended as long as it serves American interests. The US does not want to bind itself with an institutional chain that will weaken its field of action and strong hand. At this level, an approach based on moral superiority can only appear as an ideological approach that supports American interests. As a matter of fact, a similar approach was carried by Britain until 1918, the period before the US took the leadership after 1945. Liberalism's first global hegemony was achieved through British arms and money power. In fact, the American multilateralism is closely linked to American interest and hegemony, beyond idealist and missionary perspectives.

The US claimed the leadership of the liberal and free world of the bipolar system in the global system. This leadership has been inevitable in a sense in the post-war political and power vacuum in international system. The US has also an interest in this. To take this view one step further, the multi-party liberal democratic structures or authoritarian political regimes defended to prevent the socialistslides that dominate every part of the capitalist world seemed viable only thanks to American leadership. This approach neglects two issues. International institutions, demonstrate a self-resilience and a continuity arising from their mission, which allows them to survive once established. In addition, democratic regimes continue both as an institutional structure and for reasons arising from the countries' own political pluralism. In this sense, the argument that the international liberal democratic order or the democratic regimes cannot survive without the American leadership and protection is questionable.

Thesedemocratic institutions needs to be owned for broader political legitimacy and popular base. Above all, they should have capacity to respond to practical political and economic problems. Otherwise, the liberal democracies, as in the period between the two world wars, will soon turn to authoritarian regimes and totalitarian structures (Mazower, 1998). At least historical experience shows this. Technology would only help for further control of the masses. How durable the post-war international order with a deeply integrated institutional, political and economic structure in historywill be is a key question. Perhaps the most important reality that the end of the Cold War soon revealed is that the US has 
neither the intention nor the power to carry such a leadership anymore. Clues to this have been evident for some time. The pandemic, on the other hand, has literally undermined the American multilateral international approach, which has been in a crisis of legitimacy and leadership for a long time.

\section{Conclusion}

The question that requires a response is whether it is possible to escape from the pandemic and the resulting global turbulence. Swedish politician and diplomat Carl Bildt underlined how the leading countries and the global institutions were unsuccessful in combating the pandemic (2020). According to Bildt, if the Chinese authorities had given a serious and healthy response to the danger just three weeks before they responded, the extraordinary damage experienced today would not have been experienced by 95 per cent. Indeed, outbreaks such as SARS in China (2003), MERS in Saudi Arabia (2012) and Ebola in West Africa (2014-16), which have been experienced since the early 2000s, are an epidemic like what we have already mentioned or Covid-19. It showed that such a pandemic was not a very remote possibility. Bildt argues that the main reasons for all of these were urbanization, population growth, destruction of forests and extraordinarily differentiated production and distribution processes. What was important was why the measures were taken so late despite all these known. In this context, the new type of coronavirus pandemic, which has spread rapidly due to the delay of China in informing the world and the WHO's inability to provide coordination between the great powers for a long time, manifests itself as a serious transparency problem on the one hand. On the other hand, for Bildt, it is a matter of governance, democracy and solidarity.

However, now the real problem has evolved to another point. What will happen when the pandemic is over? According to the world-renowned economist Stiglitz, the economic measures taken after the 2008 financial crisis were not carefully taken in consideration of priorities. Now, in the US, the package that Congress has made with sharp bargains better reflects what the priorities should be. Primarily, the package, which includes combating the pandemic, aims to help the most vulnerable groups. Another important goal of the package was to provide an environment for strong recovery. Stiglitz underlined that there was a growing consensus that contrary to what many governments around the world claim, the economic shutdown was going to take much longer and there would be no rapid recovery. The longer this situation lasts, the more deficiencies in the 'rescue' packages would be visible. The elections in the US, announcing the biggest aid package, showed this clearly. For this reason, the priority in economic packages and political initiatives was to restore the balance. According to Stiglitz (2020), protecting against the risks faced by a particularly complex social structure and financing advances in science and high-quality education on which longterm well-being depends is the main priority. Researchers, teachers, and the institutions that support them are areas that can be supported quickly.

Even if this crisis is over, we must be aware that a new crisis is definitely lurking around the corner if long-term investments are not made in these productive areas. We cannot predict what the next crisis will look like, according to Stiglitz. Priorities in economic support should be determined around the three major crises the world faced before the pandemic: the extraordinary inequalities developing around the world; climate crisis; health 
crisis. Underlining that priorities were not determined in this direction in the recovery packages after the 2008 crisis, Stiglitz stated that it was seen that only giving more money to companies, higher growth, more investment or higher wages could not be achieved. On the contrary, the methods applied in the previous crisis resulted in more stock buybacks and higher CEO payouts. Stiglitz argues that in order not to face the same consequences, the money transferred to large companies and banks will be possible by imposing some conditions on how that money will be used and how companies should behave. As Stiglitz says 'countries do not get rich from larger casinos, real estate empires, or even financial sectors. They would be rich in scientific discoveries and advances in technology based on those discoveries.

Another approach that deserves to be heard with the Covid-19 outbreak is the approach of the Spanish politician Javier Solana (2020). In his article written while in the hospital, Solana underlines that with the pandemic Europe faced with a crisis of historical proportions. According to him, even if what happened can be called a 'war', it is definitely not a typical war. The most important factor that makes the events different from a typical war is that an invisible enemy is shared by all humanity. Solana warns of one thing: the rhetoric of war could mislead critical decisions and push the masses into serious political traps. According to him, we should not mix inflexible leadership with strong leadership that is needed. Giving governments enough room to make emergency decisions is not the same as giving a completely open card that can mean doing whatever they want. According to Solana, maintaining the maximum protection of freedoms and holding leaders responsible is both an ethical imperative and the best line of defense against threats such as the global epidemic. Solana says that doing so will not weaken societies, but rather enrich public debate and increase the chances of identifying the most appropriate responses.

Secondly, Solana warns us that we must be able to distinguish between exclusionary forms of nationalism and patriotic responsibility that is really needed. According to Solana, it is unacceptable to succumb to panic and let go of bad instincts and seek a scapegoat. The crisis can only be resolved with rationality and mutual understanding. All ways of international scientific and technological cooperation must be explored in a spirit of solidarity that matches our own interests today more than ever. The key to overcoming the current crisis is to ensure that the global spread of best practices overcomes the global spread of the virus, according to Solana. Finally, Solana warns us that getting out of this hypothetical war should in no way be like those left behind after a real war. According to Solana, reconstruction should be designed as preventive rather than reactive, and shock absorbing mechanisms should work at full speed immediately. In this context, EU institutions should do whatever it takes to bear a global responsibility. Referring to the indispensable importance of designing an effective joint response with other multilateral platforms, Solana argues that the gains of globalization should not be forgotten and this inevitable phenomenon should be reconsidered without careful evaluation and complete rejection.

\section{References}

Authers J. (2020) "How Coronavirus Is Shaking Up the Moral Universe", Bloomberg Opinion, 29 March.

Biersteker, Thomas (1992). "The triuph of neoclassical economics in the developing world: 
policy convergence and bases of governance in the international economic order", James Rosenau and Ernst-0tto Czempiel (der) Governance without government: order and change in world politics, (Cambridge, Cambridge University Press), pp. 102-131.

Blunchflower David (2020), "Pandemic Economics: 'Much Worse, Very Quickly", The New York Review of Books, 11.

Bildt Carl (2020), "The responsibility to report", Project Syndicate, 25 March.

Boucher, David (1994). "British idealism, the state and international relations", Journal of the History of the Ideas, 55 (4): 671-694.

Carr, E.H. (1945). The Twenty Years' Crisis: 1919-1939, New York:Perennial.

Clover Joshua (2020), "The rise and fall of biopolitics: A response to Bruno Latour", Critical Inquiry, 29 Mart.

Cohen, Marshall (1984). "Moral skepticism and international relations", Philosophy and Public Affairs, 13 (4): 9-346.

Day Meagan (2020), "We Just Barely Averted a Gigantic Pandemic Grift by Big Pharma", Jacobin Magazine, 26 March, online: https://jacobinmag.com/2020/03/gilead-orphan-drugremdesivir-coronavirus.

Dillon, Michael (2007). "Governing terror: The state of emergency of biopolitical emergence", International Political Sociology, 1 (1): 7-28.

Doyle, Michael (1983). "Kant, Liberal Legacies and Foreign Affairs", Philosophy and Public Affairs, 12 (4): 205-232.

Dryzek, John (2010). "The Democratization of the Authoritarian States", John Dryzek. Foundations and Frontiers of Deliberative Governance, (0xford, Oxford University Press), pp. 135-154.

Ellis, David (2009). "On the possibility of "international community", International Studies Review, 11 (1).

Falk Richard (2020), "Can the U.S. Democracy Be Fixed?", Security Dialogues, vol. 11, no. 2.

Fine, Ben (2011). "Social capital and health", Kate Bayliss et.al. The Political Economy of Development: The World Bank, Neoliberalism and Development Research, (New York, Pluto Press), pp. 99-127.

Foucault, Michel (1991). "Governmentality", Graham Burchell et.al., The Foucault Effect: Studies in Governmentality, Chicago: The University of Chicago Press, pp. 87-118.

Frey Isabel (2020), "Herd Immunity" is Epidemiological Neoliberalism", 19 March, online https://thequarantimes.wordpress.com.

Martin Gak (2020), "Economy vs. human life is not a moral dilemma", DW Opinion, 27 March, online https://www.dw.com/en/opinion-economy-vs-human-life-is-not-a-moraldilemma/a-52942552. 
Gordon, Colin (1991). "Governmental rationality: An Introduction", in Graham Burchell et.al., The Foucault Effect: Studies in Governmentality, Chicago: The University of Chicago Press, pp. $1-51$.

Horton Richard (2020), "Coronavirus is the greatest global science policy failure in a generation", The Guardian, April 9.

Ish-Shalom, Piki (2006). "Theory gets real, and the case for a normative ethic: Rostow, modernization theory and the alliance for progress", International Studies Quarterly, 50 (1): 287-311.

Johnston, Deborah (2011). "World Bank research on HIV/AIDS: Praise where it's due", Kate Bayliss et.al.,The Political Economy of Development: The World Bank, Neoliberalism and Development Research, NY: Pluto Press.

Jones Jonathan (2020), "We are all Edward hopper paintings now: is he the artist of the coronavirus age?", The Guardian, 27 March, https://www.theguardian.com/artanddesign/2020/ $\mathrm{mar} / 27 /$ we-are-all-edward-hopper-paintings-now-artist-coronavirus-age.

LeBlanc Paul (2020), "Texas Lt. Gov. Dan Patrick: 'I'm all in' on risking my health to lift social distancing guidelines for economic boost", CNN, 20 March 2020, https://edition.cnn. com/2020/03/23/politics/coronavirus-texas-social-distancing-guidelines/index.html;

LeBlanc Paul (2020a), "Trump says 'We can't let the cure be worse than the problem itself", New York Times, 23 March, https://www.nytimes.com/2020/03/23/us/politics/trumpcoronavirus-restrictions.html.

Lijphardt, Arend (2008). "Types of democracy and generosity with foreign aid: An indirect test of the democratic peace", ArendLijphart. Thinking about democracy: power sharing and majority rule in theory and practice, (London: Routledge), pp. 232-244.

Marchetti, Raffaele (2009). "Mapping alternative models of global politics", International Studies Review, 1 (1): 133-156.

Mayo, Sam and Paris Yeros (2011). "The fall and rise of the national question", in Sam Moyoand Paris Yeros (eds) Reclaiming the nation: The return of the national question in Africa, Asia and Latin America, (London, Pluto Press), pp. 3-30.

Mazower, Mark (1998), Dark Continent: Europe's Twentieth Century, NY: Vintage Books.

Morgenthau, H. (1964). "The moral blindness of scientific man", Hans Morgenthau. Scientific Man Vs. Power Politics, Chicago: The Chicago University Press.

Morgenthau, Hans (1967). Politics Among Nations, New York: Alfred Knoph.

Nardin, Terry (2011). "Middle-ground ethics: can one be politically realistic without being a political realist?", Ethics and International Affairs, 25 (1): 7-16.

Rahnema, Majid (1997). "Development and the people's immune system: The story of another variety of AIDS", Majid Rahnema ve Victoria Bawtree (ed) The Post-development reader, (London, Zed Books). 
Reinhart Carmen (2020), "This time is truly different", Project Syndicate, 23 March, https:// www.project-syndicate.org/commentary/covid19-crisis-has-no-economic-precedent-bycarmen-reinhart-2020-03.

Rengger, Nicholas (1997). "The ethics of trust in world politics", International Affairs, 73 (3): 469-487.

Rosenau, James (1992). "Governance, order and change in world politics", James Rosenau ve Ernst-Otto Czempiel (ed) Governance without government: order and change in world politics, (Cambridge, Cambridge University Press), pp. 1-29.

Ruggie, John Gerard (1982). "International regimes, transactions and change: embedded liberalism in the post-war economic order", International Organization, 36 (2): 379-415.

Runciman David (2020), "Coronavirus has not suspended politics- it has revealed the nature of power", The Guardian, 27 March, https://www.theguardian.com/commentisfree/2020/ $\mathrm{mar} / 27 /$ coronavirus-politics-lockdown-hobbes.

Skidmore, David (1997). "Rethinking realist interpretations of the Cold War: Balance of power or competing social orders?", in David Skidmore (ed) Contested social orders and international relations, (Nashville, Vanderbilt University), pp. 165-186.

Smith, Steve (1983). "Hegel's views on war, the state and international relations", The American Political Science Review, 77 (1): 624-632.

Solana Javier (2020), "Our Finest Hour", Project Syndicate, 28 March, https://www.projectsyndicate.org/commentary/global-socioeconomic-landscape-after-covid19-pandemic-byjavier-solana-2020-03?barrier=accesspaylog.

Stiglitz Joseph (2020) "A Lasting Remedy for the Covid-19 Pandemic's Economic Crisis", The New York Review of Books, 11 April.

Tisdall Simon (2020), "Leaderless, lacking and late: a global plan to fight coronavirus is desperately needed", The Guardian, 11 April.

Tribe, Keith (2009). "The political economy of modernity: Foucault's College de France lectures of 1978-1979", Economy and Society, 28 (4): 679-698.

Varoufakis Yanis (2020), "Europe is unprepared for Covid-19 Recession", Project Syndicate, 18 March, https://www.project-syndicate.org/commentary/eurogroup-finance-ministersmisunderstand-covid19-crisis-by-yanis-varoufakis-2020-03?barrier=accesspaylog.

Vincent, Andrew (1983). "The Hegelian state and international politics", Review of International Studies, 9 (1).

Vincent, Andrew (1988). "Ethics and the Hegelian State", Bernard Cullen (ed) Hegel Today, (Avebury: Aldershot).

Waltz, Kennet (1991). "Globalization and Governance", Political Science and Politics, 32 (4): 693700. 
Waltz, Kenneth (1993). "The Emerging Structure of International Politics", International Security, 18 (2): 44-79.

Wendt, Alexander (1992). "Anarchy is what states make of it", International Organization, 46 (2): 391-425.

Weber, Max (2004). The Vocation Lectures: Science as a vocation; politics as a vocation, Cambridge:Hacket.

Zurn, Michael (2000). "Democratic governance beyond the nation-state: The EU and other international institutions", European Journal of International Relations, 6 (2): 183-221. 